\title{
Rebuilding the Namibian hake fishery: a case for collaboration between scientists and fishermen
}

\author{
$\underline{B a r b a r a}$ Paterson $^{1,2,3}$ and Paulus Kainge ${ }^{4}$
}

\begin{abstract}
One of the most important fisheries in the northern Benguela is the Namibian hake fishery, which targets both Merluccius capensis and Merluccius paradoxus. In spite of attempts to rebuild the hake stocks that were severely depleted by distant-water fleets before Namibia's independence in 1990, stocks have failed to recover. Because the ecological goal of stock rebuilding competes with social and economic objectives on the political stage, the ability to make accurate abundance estimates is important. However, the precision of abundance estimates is impeded by lack of understanding of hake behavior and of the effects of environmental factors. Furthermore, at present both species of hake are assessed and managed as one Namibian stock. We present qualitative information derived from interviews that we conducted with Namibian hake trawl and longline fishers during the 2009 and 2010 fishing seasons, and information gleaned from analyzing logbook data. We contextualize both types of data within the scientific literature on Namibian hakes and the Namibian hake fishery. Fishers monitor sea surface and bottom temperature, water quality, currents, and weather, and they have detailed knowledge about the behavior and habitat of hakes. Fishers differentiate between three different types of $M$. capensis, which they associate with different fishing areas. They also describe innovations that have taken place over the past 20 years, which are of relevance to the assessment of fishing efficiency and effort, but have not been taken into account in the stock assessments. Our analysis of logbook data supports the increase in efficiency. The results show that closer collaboration between scientists and fishers has the potential to improve the accuracy of survey estimates and stock assessments, and thus is important for rebuilding of hake stocks and the hake fishery.
\end{abstract}

Key Words: demersal fisheries; fish stock assessment; fishers' knowledge; local ecological knowledge (LEK); Merluccius capensis; Merluccius paradoxus; Northern Benguela System; social ecological systems

\section{INTRODUCTION}

The field of fisheries management has recently undergone a paradigm shift. Traditional fisheries management assumed that the productivity of fish populations was largely independent of the physical environment and social-ecological changes. Fisheries management models assumed that the recruitment of new fish could be predicted based on the size of the adult population and that the size of a fish population could be manipulated through fishing pressure. Consequently, for close to 100 years fisheries management has focused on regulating fishing pressure through, for example, the number of boats, the size of fishing nets, and the setting of a total allowable catch (Pauly et al. 2002, Bavington 2009). The new paradigm, known as an ecosystem approach to fisheries, recognizes that fisheries are social-ecological systems shaped over time by human activities that are both the cause and result of ecological change (Wilson 2006).

In the northern Benguela, Namibian fishing vessels target two species of hake, Merluccius capensis and Merluccius paradoxus. This fishery commenced in the 1950s but remained insignificant until the arrival in 1964 of distant-water fleets that exploited the hake resources beyond the sustainable limit (Sumaila and Vasconcellos 2000, Roux and Shannon 2004). Catches peaked in 1972 at over 800,000 tonnes followed by a rapid decline (Fig. 1). When Namibia gained independence in 1990, catch limits were drastically reduced to 60,000 tonnes, "to allow the stock to recover" (Ministry of Fisheries and Marine Resources 2004:2). Some 20 years later, hake spawning stock biomass is considered to be at about $80 \%$ of values in 1990 and $12 \%$ of values in 1964 (Kirchner et al. 2012), a level that the Food and Agriculture
Organization of the United Nations classifies as "depleted" (Marine and Inland Fisheries Service 2011). What happened?

Fig. 1. Reported landings and total allowable catch levels for Namibian hakes, 1964 to 2012. Source: Namibia Ministry of Fisheries and Marine Resources.

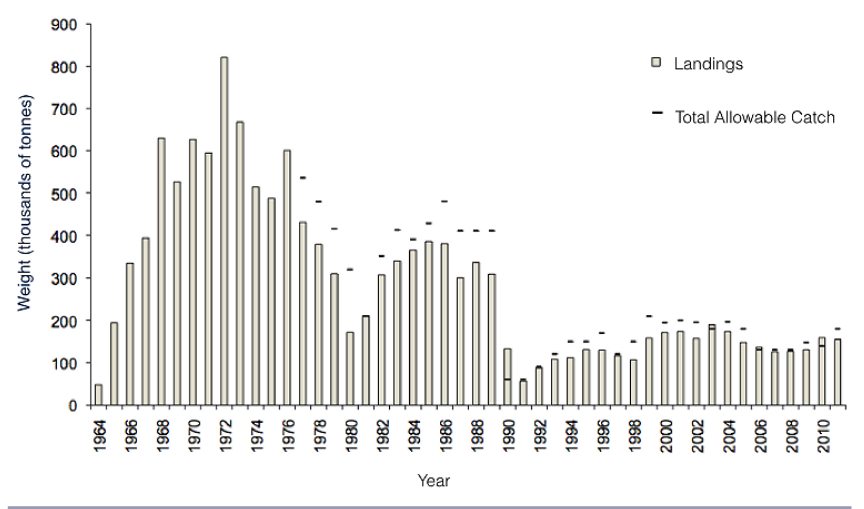

As a direct result of the effort by distant-water fleets, Namibia at independence inherited an altered ecosystem well below its productive capacity (Roux and Shannon 2004). Sumaila and Vasconcellos (2000) estimated that foreign fishing effort cost Namibia $50 \%$ of the economic rent that could otherwise have been obtained. Unsurprisingly, when Namibia took over the management of its marine resources in the early 1990s the main

${ }^{1}$ Community-University Research for Recovery Alliance (CURRA), Memorial University of Newfoundland, ${ }^{2}$ Marine Research Institute (Ma-Re), University of Cape Town, ${ }^{3}$ Department of Finance, Information, Systems, and Management Science, and School of the Environment, Saint Mary's University, Nova Scotia, ${ }^{4}$ National Marine Information and Research Centre (NatMIRC), Namibia Ministry of Fisheries and Marine Resources 
focus was on rebuilding Namibian commercial fish stocks and fisheries. Potential uncontrolled foreign fishing was addressed through the declaration of a 200-mile (322-km) exclusive economic zone in 1990. Namibia created a fisheries institute and put in place a research program involving regular 'at sea' surveys. Based on the high catch rates of previous decades, the government estimated that after a short (unspecified) period of recovery the hake stocks would support long-term sustainable catch levels of 250,000 to 300,000 tonnes (Ministry of Fisheries and Marine Resources 1991 as cited in Sherbourne 2010).

The newly appointed Namibian scientists initially reduced catch limits to 60,000 tonnes but this was contested by some scientists, including South Africans, who "were stunned by the conservativism [sic] of the initial total allowable catch recommendation by the new government" (Ocean and Land Resource Assessment Consultants 2013). From the outset, then, there was scientific disagreement regarding the size of the resource and the anticipated rate of rebuilding: survey-based estimates indicated overexploitation, while estimates based on commercial catch and effort data indicated nearly pristine abundance levels (van der Westhuizen 2001). On the strengths of the high catch levels of the past, and based on related high expectations regarding the productivity of the resource (Sherbourne 2010), and in response to challenges from external scientists to the size of the original post-independence quota (Paterson et al. 2013), the Namibian government increased the total allowable catch levels from 60,000 in 1990 to 200,000 in 1999 (Fig. 1). Scientists hired by the industry encouraged the government to move in this direction, pleading their case "in writing and verbally to meetings of the Namibian Fisheries Advisory Committee .... [As a result,] the crippling total allowable catch reductions proposed by some of the [Namibian] scientists have not been implemented" (Ocean and Land Resource Assessment Consultants 2013). This is why Namibia's hake industry in 2013 has the capacity to catch and process 300,000 tonnes of fish a year, despite having actually achieved average landings of less than half of that amount in the years between 1990 and 2010 (Fig. 1).

Clearly the high expectations for the hake fishery have not been met: landings have in most years remained lower than the annual total allowable catch (Fig. 1). The recent draft management plan estimates that "sustained catches in the order of 150,000 to 200,000 tonnes may be the maximum possible" (Ministry of Fisheries and Marine Resources 2011b:11). The early confusion over the accuracy of abundance estimates, exacerbated by weak data and challenges from industry-funded scientists, has been obscuring the failed resource recovery. The confusion has also weakened the political influence of nonindustry fisheries scientists in the face of conflict between the ecological goal of stock rebuilding and the equally important social and economic objectives.

\section{Assessment and management approaches}

Since 1998, the total allowable catch for the Namibian hake fishery has been determined each year by adjusting the previous year's total allowable catch up or down depending on whether the size of the resource is thought to have increased or decreased. The rate of change is calculated based on two indices: the commercial catch per unit of effort (CPUE) and an abundance index from averaged annual scientific surveys (Butterworth and Geromont
2001). These are then entered into an age-structured production model (Rademeyer et al. 2008) that estimates the size of the resource, by using these data along with proportions of fish caught per age class (from survey and commercial catches) and the mean weight of fish per age class (from survey measurements) (Butterworth and Geromont 2001, Wilhelm 2012).

The accuracy of abundance estimates is obviously of central importance to fisheries management, but estimates based on CPUE data are problematic because standardized CPUE data do not account for increased efficiency in the fishing fleet or for spatial and temporal intensification (Pennington and Stromme 1998, Neis et al. 1999b, Neis and Kean 2003). In addition, range contraction in remaining stocks may keep landings in mobile trawl fleets high, despite depletion (Hutchings 1996, Bennet 2008). Survey data are based on a systematic transect design, with a semirandom distribution of stations along transects and standardized effort and efficiency over time. However, these data are subject to bias due to systematic sampling errors and lack of understanding of fish behavior (Johnsen and Iilende 2007). Both survey and CPUE data are major inputs into the Namibian hake stock assessment model. The two indices have not shown the same trend since 2009, with CPUE increasing but the survey data showing a downward trend. A similar phenomenon was observed for Newfoundland cod and ignored - followed by the collapse of the cod stocks of the northwest Atlantic, with catastrophic consequences for coastal communities (Finlayson 1994). It is thus crucially important that ongoing disputes about the meaning of the signals from these data sets cease and Namibian scientists resolve the key factors affecting the precision and accuracy of estimates based on these data. Only if understanding is thus improved and scientific advice adhered to, by both the Marine Resources Advisory Council and the Minister, will Namibia be in a position to rebuild these fisheries. Fisheries stock assessment requires a good understanding of the dynamics of fisheries (Hilborn and Walters 1992) in order to correctly interpret fisheries-dependent data.

One way to address the need for information about both the social and the ecological circumstances affecting fisheries is to draw on insights from different groups of knowledge holders, including scientists and commercial fish harvesters. Social-ecological research seeks to systematically collect the local ecological knowledge of commercial fish harvesters and compare it with science, looking for points of convergence and divergence (Haggan et al. 2007, Lutz and Neis 2008, Berkes 2011, Ommer et al. 2012, Dawe and Schneider 2014). A growing body of scholarship has highlighted the potential value and associated risks and challenges of integrating fishers' knowledge into fisheries science and management (Agrawal 1995, Nadasdy 1999, Neis and Felt 2000, Soto 2006). In particular, local fishers can provide insights not captured by the quantitative data that are routinely used in fisheries stock assessments and which can help to interpret catch data from commercial fisheries, including CPUE estimates (Neis 1992, Johannes and Neis 2005). Moreover, such information can be made usable in quantitative stock assessments (Neis et al. 1999b). Murray et al. (2008), for example, have shown that the ecological knowledge of harvesters provides a valuable local scale complement to scientific information about cod migration and stock structure in the northern Gulf of St. Lawrence in Newfoundland, Canada. Most of the existing 
research on commercial fish harvesters' ecological knowledge and science has focused on long-standing, small-scale fisheries; exceptions are Hind (2012) and Carruthers and Neis (2011). Here we present qualitative information from interviews with captains of Namibian, industrial, demersal, trawl and longline vessels, and we present information resultinf form out analyses of logbook data. We contextualize both types of data within the scientific literature on Namibian hakes and the Namibian hake fishery, and conclude by making a case for the contribution of fishers' knowledge to the efforts to rebuild Namibian hake stocks and to lay the foundations for a future sustainable fishery.

\section{METHODS}

\section{Fisher data}

We analyzed, using MS Excel, commercial fishing data on hake from fishery logbooks collected by the National Marine Information and Research Center (NatMIRC). For the demersal trawl (wetfish) fishery we used data for the years 2003 to 2005 to calculate the spatial distribution of effort as number of trawls per year per fishing area. For the demersal longline fishery, we analyzed data for the years 1999 to 2012 that included information on date, time, length, location, and depths of lines set; number of hooks per set; and amount of fish caught, in order to calculate change in effort. We also consulted the academic literature on the Namibian fisheries; publications from the Ministry of Fisheries and Marine Resources; and relevant dissertations, technical papers, and project reports.

\section{Interview data}

Fieldwork was conducted in 2009 and 2010 in Walvis Bay, Namibia, using multiple methods to contact captains. The demersal longline and trawl fleet is comprised of corporateowned vessels: at that time 63 demersal trawl vessels and 13 longline vessels were licensed to operate in Namibian waters, but it is not known how many were active (Ministry of Fisheries and Marine Resources 2011a). Because there was no list of active captains we presented our research plan to the chairperson of the Namibian Hake Association and to the managing directors of companies operating vessels targeting hake who provided initial contact details for captains. We used snowball sampling (Biernacki and Waldorf 1981) to identify additional captains by asking participants to name others they considered experienced in this fishery. It is impossible to determine the sampling error because this sampling method is not based on random selection, but it allowed us to focus on a subsample of captains who were reputed to be highly experienced in the fishery, which is similar to the methodology recommended by Davis and Wagner (2003). We conducted semistructured interviews - following the methodology for local knowledge interviews with fishers described by Neis et al. (1999a; also see Murray et al. 2006) — with eight trawl and six longline skippers who fished in the study area (Fig. 2). In 2009 these captains had a minimum of 12 and a maximum of 40 years of fishing experience, and had worked in Namibian waters between 5 and 40 years and in the hake fishery (in Namibia and South Africa) between 5 and 31 years. In addition, participant observation was carried out at sea during a 4-day fishing trip aboard a Namibian trawl vessel. Interviews were audio recorded and transcribed. The data were coded and categories and themes were constructed (Henning 2004) using TAMS Analyzer (Weinstein 2012). The quotations used here reflect common themes. To honor our obligation to consider risks and benefits that may derive from participation in our research (Maurstad 2002, Carruthers and Neis 2011) we provided sufficient information to allow participants to give free and informed consent by explaining the research process in writing.

Fig. 2. Map of the Namibian fishing area for hake; fishing takes place along the entire coast and concentrates at depths of 200 to $400 \mathrm{~m}$.

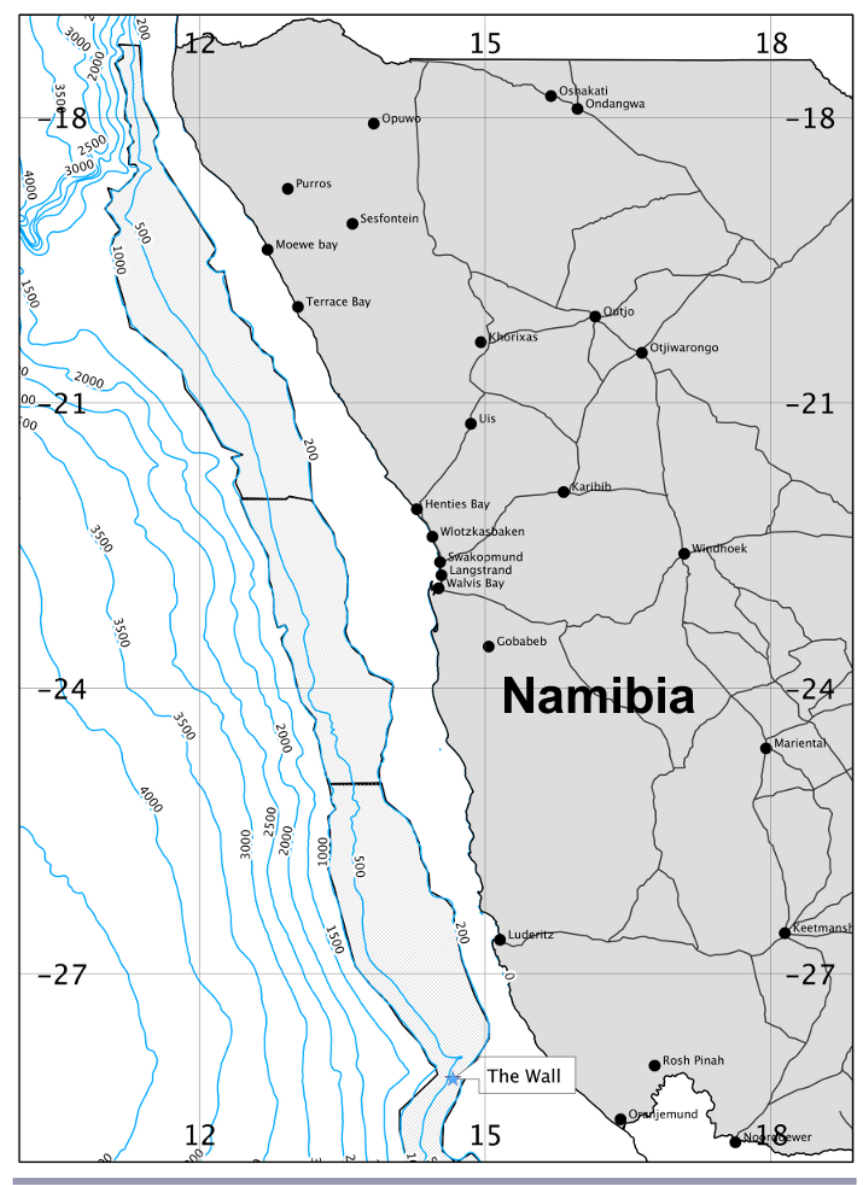

\section{RESULTS}

The trawl skippers operate wetfish trawlers with a loading capacity of 60 to 80 tonnes of fresh fish packed on ice. Vessels range between 28 and $48 \mathrm{~m}$ in length and measure 268 to 838 GRT (Benguela Current Large Marine Ecosystem 2006). Trips are up to 8 days long. Trawling involves dragging a net behind the vessel across the seabed. During fishing, the net is kept open and close to the ground by heavy metal doors, while the vessel moves at a very slow speed (about $6 \mathrm{~km} / \mathrm{h}$ ). The length of a trawl depends on the amount of fish that is being caught and can be as short as 1 $\mathrm{h}$ in the case of "heavy fishing", and as long as $4 \mathrm{~h}$ "when the fish is scarce", according to the fishers.

The longline vessels have a loading capacity of about 35 tonnes of fish. Vessels are between 20 and $35 \mathrm{~m}$ long and measure 100 to 354 GRT (Benguela Current Large Marine Ecosystem 2006). Longlining is a fixed gear fishing technique using hooks and line. 
In Namibia, a typical longline is $32 \mathrm{~km}$ ( 20 miles) long and set in one or two parallel sections. The longlines are secured and their position marked by anchors and buoys. Fishing lines are attached to a top line and submerged 1 to $2 \mathrm{~m}$ above the seabed by means of weights and floats. At 1-m intervals, short pieces of line, each with a baited hook at the end, are attached to the fishing line. Trips last up to 8 days, the catch being put on ice to keep fresh.

We present the results from the interviews in four sections: (1) fishing locations, (2) vertical migration, (3) stock structure, and (4) effort and efficiency. Pseudonyms are used to protect the captain's identities. Two sections include results from logbook analyses.

\section{Fishing locations}

Fishing for hake takes place all along the Namibian coast, at depths between 200 and $1000 \mathrm{~m}$, with no trawling or longlining allowed $<200 \mathrm{~m}$ depth. The fishing area can be divided into three sections. The central area stretches from Henties Bay $\left(22^{\circ} \mathrm{S}\right)$ to halfway between Walvis Bay and Luderitz $\left(25^{\circ} \mathrm{S}\right)$. The northern area stretches north from the central area $\left(22^{\circ} \mathrm{S}\right)$ to the Angolan border $\left(17^{\circ} \mathrm{S}\right)$. The southern area stretches from the central area south $\left(22^{\circ} \mathrm{S}\right)$ to the South African border $\left(30^{\circ} \mathrm{S}\right)$ (Fig. 2). Starting in 1991 (Petersen et al. 2009), longliners initially operated out of Luderitz, a smaller harbor on the southern part of the Namibian coast. Since then, more companies have moved their longline vessels to centrally located Walvis Bay and by 2009 the majority of the fleet was operating from there. Longliners target shallow water hake (M. capensis) at depths of 200 to $500 \mathrm{~m}$ (based on logbook data for 2010, 3557 records, average depth $320 \mathrm{~m}$ ); they concentrate in the south, in the area between Luderitz and Oranjemund, in the central area just north and south of Walvis Bay, and in the north in the area off Moewe Bay $\left(19^{\circ} \mathrm{S}\right)$.

Most of the trawler fleet also operates out of Walvis Bay. Because of the mobility of the fishing gear and the greater capacity of most of the vessels, that fleet operates more widely, from the Angolan border in the north to the border with South Africa in the south (Fig. 2), at depths of 200 to $1000 \mathrm{~m}$. However, some $70 \%$ of the effort concentrates at depths of 200 to $400 \mathrm{~m}$ and effort decreases to $8 \%$ at depths $>600 \mathrm{~m}$. Between 2003 and 2005, 40\% of all trawl sets were made in the central area (Table 1); more than half of these were in the area between Henties Bay and Walvis Bay.

\section{Vertical migration}

Both $M$. capensis and $M$. paradoxus undergo vertical migration away from the seabed (Payne 1995). This behavior affects their catchability by bottom trawl gear and introduces a variable bias into the results of bottom trawl surveys because a proportion of the fish is excluded from the biomass estimates (Iilende et al. 2001). The trawlers report better catches during the daytime when the fish are closer to the bottom than at night when they rise into the midwater. This corroborates findings by Johnsen and Iilende (2007) who investigated diel (24-h periodic) variation in commercial CPUE, based on logbook data. They also suggest that the vertical migration of hake and a reduced herding effect due to reduced visibility are the factors most likely impacting catchability at night. They found that diel variation decreased with depth and varied with latitude, and suggested that this may be a consequence of changes in species composition from $M$. capensis to $M$. paradoxus, along with larger fish, and unrecorded environmental conditions. Trawl skipper Jim confirms this observation:
Nah [the paradoxus] stays on the bottom. You don't need a net with a 20-meter opening to catch it. You can catch it with a net with a 1-meter opening almost. Because you can't see him on the echo sounder; you can't even see whether there is something on the bottom. But if you put your net in the water you always catch something.

Table 1. Number of trawls per fishing area and by degrees of latitude, 2003 to 2005. n=127584. Source: Namibia Ministry of Fisheries and Marine Resources' logbook data.

\begin{tabular}{lccc}
\hline \hline Area & $\begin{array}{c}\text { Latitude } \\
\text { (degrees) }\end{array}$ & $\begin{array}{c}\text { Trawls } \\
\text { (no.) }\end{array}$ & $\%$ \\
\hline North & 17 & 6,211 & 5 \\
& 18 & 5,174 & 4 \\
& 19 & 9,455 & 7 \\
& 20 & 7,965 & 6 \\
Total & 21 & 5,605 & 4 \\
& & 34,410 & 27
\end{tabular}

$\begin{array}{cccc}\text { Central } & 22 & 24,814 & 19 \\ & 23 & 12,287 & 10 \\ & 24 & 9,746 & 8 \\ & 25 & 3,628 & 3 \\ \text { Total } & & 50,475 & 40\end{array}$

$\begin{array}{cccc}\text { South } & 26 & 9,225 & 7 \\ & 27 & 16,285 & 13 \\ & 28 & 6,233 & 5 \\ & 29 & 10,956 & 10 \\ \text { Total } & & 42,699 & 33\end{array}$

Grand total

127,584 100

Trawler captain Michael, who prefers to target M. paradoxus in water deeper than $640 \mathrm{~m}$, reports that in the deep water the pattern is reversed:

Normally like me myself I am in the deep. [. . .] it's always like this: night time I get better fish than daytime. But that's only in the deep. [In the] shallow water, only daytime fish. So, what the guys usually do, is in the day time [they fish in] the shallow, in the night they run out to the deep.

Both longline and trawl skippers report that in very cloudy conditions the hake stay off the bottom and are difficult to catch. Longline skipper Allan explains:

And another thing, here in Walfish [sic] Bay, especially, because you got a lot of cloud cover here, fish when it's very, very cloudy; the fish never goes down to the bottom. It normally stays here in midrange, in mid water. And as soon as you get a bit of sunlight the fish goes down to the bottom. You can hear the guys the trawlers also talk about that [...]. That is a fact that I have seen. 
Trawl skipper Dave agrees:

Sometimes it is important that there is sunshine. In shallow water it seems to matter. The sun shining in the shallow water, the [echo sounder] marks seem to go onto the bottom, [that is] the fish. In the deep water it doesn't seem to matter.

\section{Stock structure}

Common stock assessment techniques assume discrete populations. However management units are the result of political and administrative considerations and do not always match biological population structure. Although conserving fish stock structure is a critical aspect of preserving biodiversity, stock components are difficult to determine from traditional fisheries data (Stephenson and Kenchington 2000).

\section{Horizontal migration}

Knowledge of fish movement is important because it has implications for stock structure. Knowledge about the movement of $M$. Capensis would help to tell us whether there are local substocks of $M$. Capensis in Namibia. The reasons for and patterns of horizontal migration of hakes in the northern Benguela, and their effects on distribution, are not well understood by science (von der Heyden et al. 2007). It is difficult to conduct tagging studies because hake seldom survive being brought on board from the deep water.

In South Africa, both hake species migrate horizontally inshore and southwards (Payne 1995, Millar and Field 2002 cited in Gordoa et al. 2006) and it is assumed that hake migrate inshore to spawn (Gordoa et al. 2006). Namibian trawl and longline skippers corroborate this assumption:

We see [the fish] got egg and it's like red underneath and it's been rubbing on the bottom. We know it's moving to the inside, it's going into the shallows to do its thing. We chase it. Coz we like those, we like those big, big fish.

Longline skipper Phil agrees:

When we know the fish has got eggs, doesn't matter in the deep as well, then you know the fish is gonna go shallow. [...] If you lose the fish then, you know the fish got plenty eggs, then you try in the shallow waters.

Moreover, longline skipper Allan has observed that spawning fish tend to be caught in concentrations and are not normally mixed with nonspawning fish. Because they move fast, they are difficult to catch. Both trawlers and longliners agree that big hake are on the move and do not stay long in an area. Trawler captain Luis explains:

If you get a school of very nice size hake it will last a day or two, at the most 3 days, then it's gone.

Allan reports that hake movement exhibits different patterns in the south and in the north. In the south where the ground is much more varied, hake move in a circular pattern within particular areas and seem to stay within these areas, while on the northern longline grounds, they seem to move longer distances-16 to 32 $\mathrm{km}$ (10 to 20 miles) in one night. Allan says:

In the 21 degrees the fish tend to go into like a circle type thing, in 1 degree. [It's] like the water rotates. In that area it will go from the shallows out to the deep and then back up again, but in like a northerly direction and back in; [the fish] move in a like, circle type move. And then come back; normally back to same place again. Why? I don't know. It's only here in the north; in the south it works completely different.

Hake trawler skippers have also observed a change in distribution of the catches. Luis reports:

We got to run further now for fish. Some areas haven't seen fish for quite a while [...]. So we're passing through those areas without even wetting our nets.

\section{Different types of $M$. capensis}

Genetic information regarding the Namibian hake stocks is limited. Burmeister (2005) considers M. paradoxus to be a shared stock between Namibia and South Africa, whereas a study by von der Heyden et al. (2007) showed significant genetic differences between $M$. paradoxus in the two countries. According to the same study, $M$. capensis is genetically highly diverse, but no genetic differences between South Africa and Namibia were found. A previous study by Grant et al. (1987) suggested that the existence of separate stocks might be assumed for management purposes. Thus the limited genetic data available are somewhat ambiguous (Grant et al. 1987) and require further research (von der Heyden et al. 2007).

Namibian longline skippers differentiate between several types of M. capensis, which they refer to as "white" (or "silver"), "brown", and "black" hake. Comparing the three types, skippers stated that black capensis is a long slender fish, whereas as Allan explains:

The white hake, the head is a bit smaller and [it is] a much bigger fish, more elongated and more heavier, [...] if you get a 60-centimeter fish, it will be at least half a kilo heavier. The brown hake? How would I say, how can I say it now. It looks like a white hake, it's just more dark in color and complexion. But it also got a nice weight to $i t$, very nice weight.

He further reports that white capensis has much bigger roe, "the size of a man's hand", than black capensis. The brown capensis has the same characteristics as the white capensis except for its slightly darker color; both are caught in the southern fishing area. The most preferred type is white capensis, but some skippers consider brown capensis to be the very best quality. Allan and Carl describe a popular fishing area for longliners at "the Wall" at $29^{\circ} \mathrm{S}$ (Fig. 2): there, the sea bottom falls from a shallow $180-\mathrm{m}$ plateau to a 550-m depth over 3 to $5 \mathrm{~km}$ ( 2 to 3 miles), forming a steep slope. Longliners report catching white capensis on the shallow parts and brown capensis on the deeper parts of the slope. North of Walvis Bay, only black capensis is caught.

\section{Effort and efficiency increases}

Fishers report that they make constant improvements in their fishing gear. In the trawl sector net openings have increased from 3.6 to $14.0 \mathrm{~m}$. Trawl skipper Michael states:

The guys were only using the Spanish trawl. Now they are more versatile. [...] You get the smaller guys, who will get a 3.6-meter opening, our big vessels 4 meter. Now the guys is using 8-meter, 12-meter, you know, just to get more opening to get more fish in. 
Table 2. Changes in fishing gear, from past to present.

\begin{tabular}{|c|c|c|}
\hline Gear & Past & Present \\
\hline Topline & & Polypropylene: $12 \mathrm{~mm}$ \\
\hline Fishing line material & Needed replacement every season & $\begin{array}{l}\text { Monofilament line: in use since } 2007 \text {; better catches (incl. } \\
\text { bigger fish) because less visible, less smell, and less vibration } \\
\text { in the water } \\
\text { Nylon line: very expensive, breaks easily }\end{array}$ \\
\hline Strength of fishing line & $6 \mathrm{~mm}$ & 1.2 to 2 or $4 \mathrm{~mm}$ \\
\hline Length of fishing line & 15.5 to $23.2 \mathrm{~km}$ & 29 to $43.5 \mathrm{~km}$ \\
\hline Hook size & & Number 2,3 , and 4 hooks \\
\hline Number of pots & 80 to 120 pots, 4 lines per pot & $\begin{array}{l}\text { Up to } 200 \text { pots } \\
3 \text { to } 4 \text { lines per pot or "caja" (square pot): cajas are easier to } \\
\text { stack than round pots and thus produce less wastage (pots } \\
\text { that fall over are un-usable) }\end{array}$ \\
\hline Swivels & None & $\begin{array}{l}\text { Keeps hook away from line, resulting in } 20 \% \text { increase in catch } \\
\text { rate, and bigger fish }\end{array}$ \\
\hline
\end{tabular}

Jim explains that the wider openings are used to make up for the decreased catchability during the night:

Like the normal bottom trawls we are working here is giving you only 4 meters. The semi-pelagic is giving you 14, 14 meters open. So [...] what we [do], actually, in the nighttime we switch over to the semi-pelagic, so we catch a bit more.

Fishing gear in the longline fishery has also changed over time (Table 2). Instead of tying the hook directly to the fishing lines, a swivel is now placed between the hook and the line, which permits the hook to turn independently from the line to which it is attached. Allan discusses the impact on catch rates:

When we started off, we never even used to put swivels on the lines [...]. So the fish never wanted to bite, because it was so close to the line it was visible. So as soon as you put swivels on, the catch rate started going up by, like, 20 per cent, 25 per cent.

Logbook data confirm that while the number of hooks set per year has decreased since 2005, the catch per hook has increased (Fig. 3), suggesting an increase in efficiency.

Bob compares the longline gear applied today in Namibia with his experience of fishing in South Africa in 1991:

Ninety-one, but that's in South Africa. And then, ja, and then what we did there, I mean shhrrr, the way we fished there, we caught so much fish and I don't even know how it happened that we caught a lot of fish, with no gear. I mean we shoot like up to 20, some boats are shooting up to 27 miles [43 km] of gear here. There we were shooting 1.2 miles [2 km]. The fish was coming, it was laying all over the deck, you know, ja. The fishing was awesome then, look I take this gear that we work with here [...] to South Africa, I think it will be like a movie.

Effort in the South African longline fishery has since increased. Nonetheless it remains lower than in the Namibian fishery with approximately $21 \mathrm{~km}$ (13 miles) of line and 10,000 hooks in the former (M. Goren, personal communication) as opposed to 20,000 hooks (J. Paterson, personal communication) and up to $43 \mathrm{~km} \mathrm{(27}$ miles) of line in Namibia.

Fig. 3. Effort and commercial catch per unit of effort (CPUE) in the Namibian hake longline fishery, 1999 to 2012. Data source: commercial logbook data, Namibia Ministry of Fisheries and Marine Resources.

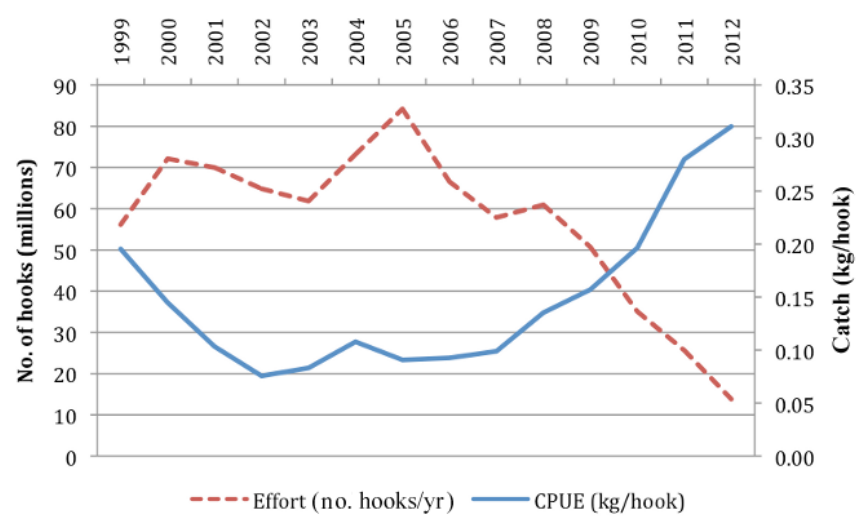

\section{DISCUSSION}

\section{Fishing locations}

The logbook analysis of trawl distribution suggests that a disproportionate amount of fishing effort takes place in the central area. This area has also been identified as a major spawning area for M. capensis (O’Toole 1976, O’Toole 1978, Assorov and Berenbeim 1983, Olivar et al. 1988, Kainge et al. 2007). Management measures aimed at protecting spawners and young fish are in place, including the closed area shallower than $200 \mathrm{~m}$ deep and the annual closed season during October. However, spawning takes place outside of October (O'Toole 1976, O'Toole 1978, Assorov and Berenbeim 1983, Olivar et al. 1988, 
Kainge et al. 2007) and the concentration of fishing effort on the area at depths between 200 to $400 \mathrm{~m}$ highlights the possibility of fish being intercepted during the spawning migration.

\section{Vertical migration}

The variability of the vertical behavior makes quantification difficult. Thus, better understanding of the phenomenon is needed in order to improve the accuracy of abundance estimates from demersal trawl surveys (Iilende et al. 2001). The Namibian surveys are conducted on board a commercial fishing vessel with demersal trawl gear. Not all depth strata are covered at night. Both hake trawl and hake longline are demersal fishing operations that are geared towards catching hake on the seabed. Consequently, skippers are acutely aware of the movement of hake up and down the water column, and they adjust their fishing strategy accordingly, e.g., shifting to deeper water and using nets with wider openings to increase night catches. Johnsen and Iilende (2007) investigated the effect of hake behavior on commercial catches. They realized that variation observed in the CPUE cannot be taken as a direct reflection of catchability because changes in fishing strategy may be responsible for increased depth at night. The reasons for this kind of strategy change cannot be gleaned from logbook analysis. Further research conducted in partnership with fishers is required to improve understanding of the complex environmental, ecological, and social processes underlying changes in catch rates. Skippers also report that catchability is affected not only by time of day, but also by season and cloud cover. Thus collaboration between scientists and fishers will potentially contribute to a better understanding of the factors affecting vertical migration and catchability, which is necessary for improving the accuracy of survey results and, consequently, the accuracy of the stock assessment.

\section{Stock structure}

\section{Horizontal migration}

There is only limited scientific knowledge about the movement of hakes and it is impossible to conclude from logbook data whether or not there is a direct link between hake behavior and environmental signals. The systematic collection of qualitative data on such observations through interviews with skippers can contribute to a better understanding of this relationship. Longliners, in particular, take notice of the movement of fish aggregations because the nature of their fishing gear and method forces the fishers to be stationary for a period of $24 \mathrm{~h}$. Therefore these fishers want to have a clear understanding of the position and anticipated movement of the fish before they commit to a fishing spot and set their lines. Consequently, they spend time observing fish movement through their echo sounders and plotting the position of fish shoals to collect observational information regarding the movement of hake at small spatial and temporal scales as a matter of course.

Skippers' observations of a spatial dynamic to hake aggregations may be indicative of the existence of substocks and thus warrant further investigation. Add to this that trawl skippers report changed distributional dynamics, and that scientific information shows a depressed biomass and failure to rebuild the Namibian M. capensis stock, and it is possible that range contraction and improving knowledge of movements may be sustaining the availability of $M$. capensis to commercial fishing in the context of declining abundance. In Atlantic Canada, cod (Gadus morhua) stocks that underwent large declines in abundance displayed increased aggregation (Myers and Cadigan 1995, Smedbol and Wroblewski 2002). Although M. capensis are not considered a schooling species, fish of similar size tend to be found in aggregations (Gordoa and Duarte 1991, Burmeister 2001), and thus potential links between hake biomass, patterns of change in aggregation, and catch rates should be investigated. Given that tagging studies are not feasible, a study based on field observation is one alternative option. A combined research project involving fishers and fisheries scientists may be able to take advantage of the skippers' high-resolution information on hake distribution to learn more about horizontal migration and the aggregation behavior of hakes. For this, scientists would need to spend time trying to understand the way skippers know the fish and how they make sense of their movement.

Interviews with trawl skippers, who at times target $M$. paradoxus, have the potential to provide information about their migration between South Africa and Namibia, which is currently disregarded in the assessments in both countries. Close collaboration would allow joint development of a research design (Stanley and Rice 2003) and in-season assessment (Stephenson et al. 1999) that would make it possible to collaboratively test assumptions regarding horizontal migration and range contraction in a way that is acceptable to both fishers and scientists.

\section{Different types of $M$. capensis}

Genetic studies thus far have been concerned with the question of whether the populations of hakes in the Benguela migrate across geopolitical boundaries because the existence of internationally shared stocks has implications for management and landings in the two countries. Whether there are genetically distinct populations at an even smaller scale, i.e., within the northern Benguela, has not been addressed in genetic research. Given the drastic decline in biodiversity at all levels (Worm et al. 2006), consideration of the potential effects of diversity within species on ecosystem functioning is important. It is also important to note that traditional stock identification techniques can fail to differentiate between populations, which are known to have been temporally or spatially distinct (Stephenson and Kenchington 2000)

Interviewed Namibian longline skippers described differences in appearance and behavior among $M$. capensis that seem to be linked to geographic areas, suggesting that there are multiple hake stocks within Namibian waters. Morphological differences in other species of marine fish have been used as a basis for assuming the existence of separate stocks (e.g., Draganik and Sachs 1991, Beckley and van der Lingen 1999) but differences in color can also be caused by diet (Gosse and Wroblewski 2004). Approaches to defining stocks using a combination of body morphology and geographic difference are considered unsuitable for hakes in the northern Benguela because there are few pronounced environmental differences within their range (Grant et al. 1987). However, the so-called "Wall" immediately north of the Orange River, where longliners differentiate catches of "white" and "brown" capensis, is a distinct feature of marine geography within the Namibian distribution of $M$. capensis. The fact that fishers report catching two types of $M$. capensis in different areas of the Wall, and at different depths, might point to different habitat 
conditions and diet, which could be the reason for the morphological difference.

The Namibian stock assessment model currently does not distinguish between $M$. paradoxus and $M$. capensis, let alone between different subcomponents of the $M$. capensis stock; this opens up the possibility of the existence of a serial depletion of subspecies and populations and a corresponding reduction in biodiversity (genetic and behavioral) in these fisheries. If more effort were made by fisheries scientists to involve fishers in the data-collection process, it may be possible to separate landings data based on subspecies, or at least, given spatial and temporal differences in distribution, to begin to estimate fishing mortalities at this level. Skippers are routinely providing logbook data on catches as part of the fisheries regulations. Moreover Namibian skippers have stated during a stakeholder workshop that data accuracy and format could be improved if they were involved in the research (Uanivi et al. 2010). The fishers and the companies that employ them would consequently have a better understanding of how the information they provide is used.

\section{Effort and efficiency increases}

Johnsen and Iilende (2007) mention the wide range in the size of net openings employed in the Namibian demersal trawler fleet, noting the increasing use of highlift nets since 2002, but they do not seem to have access to detailed data on this or on trends over time. The suggestion that efficiency in the longline fishery may have increased by up to $25 \%$ is noteworthy because, in the assessments, fishing effort in the longline fishery is normally quantified in terms of numbers of hooks set per day, avoiding the problem of changes in the number of hooks per line. However, this quantification does not reflect increases in efficiency through reduced visibility of the fishing lines or use of swivels, nor the effect of better fish-finding technology and knowledge of fish behavior on catch rates. Trawl effort is measured as number of hours trawled, standardized according to vessel size, and does not take into account net size and engine power. In addition, improved fish-finding equipment, knowledge of fish movements, aggregation, and shifting across stocks are likely to increase fishing efficiency relative to abundance, offsetting the effects of resource decline. The Namibian stock assessment methodology assumes efficiency in the fleet to be constant (C. Kirchner, personal communication) and, because this assumption is clearly inaccurate (efficiency has been increasing rather than decreasing), the result is likely positively biased stock assessments based on commercial CPUE assessment (Neis et al. 1999b). A closer investigation and quantification of this trend are opportunities to involve fishers in the assessment process, with the potential to improve the accuracy of the assessments.

\section{CONCLUSION}

Our analysis shows that, notwithstanding Namibia's efforts to rebuild its most valuable fishery, the resource remains depleted. At the same time, lack of understanding of hake behavior on the one side, and the social and ecological factors affecting fishing behavior on the other, lead to inaccuracies in the current assessment of resource abundance. Our research shows that there are many points of convergence-i.e., between the experiencebased knowledge of fishers and the quantitative knowledge that underpins fisheries science and management in Namibia, particularly recent logbook analyses-relevant for improved stock assessments and management.

Systematic collection of fishers' information is important. When fishers' information matches scientific information, uncertainty in the assessment is reduced and fishers' confidence in the assessment is strengthened. When the information diverges, further investigation of both types of information is required, which will ultimately strengthen the knowledge base (Neis et al. $1999 b$ ). However, we have also shown that there are details that are not being captured either in the logbook data or in the surveys. These details - such as information on stock structure, the spatial distribution of different stock components, and fishing efficiency - are potentially important for making accurate assessments of stocks and for undertaking improved management. Erosion of subcomponents leads to reduced intra-specific diversity. Thus, good knowledge of stock structure is important for maximizing the resilience of the stock. Moreover, disregarding efficiency increase and fishing strategy leads to inflated indices of abundance based on CPUE data.

Qualitative information from in-depth interviews and jointly designed research projects has the potential to improve the accuracy of Namibian hake stock assessment. Thus, engaging fishers more directly in gathering and interpreting the data used in stock assessments could help strengthen this knowledge. However, close collaboration between scientists and fishers contains potential risks for fishers and fishing companies because improved accuracy and inclusion of efficiency considerations may result in decreased quotas. Equally, in-depth knowledge of the information underpinning the assessment process and associated uncertainties may lead to directed efforts by the industry to manipulate information to avoid quota reductions. Clearly, this is a complex problem and there is no easy solution. However, the rebuilding of the Namibian hake stocks is in the interest of all who have a long-term stake in the fishery, including Namibian society as a whole.

The rebuilding of the hake resource is impeded not simply by limitations in current fisheries science but also by total allowable catches that are set well above the scientific recommendation (Fig. 1, Paterson et al. 2013). This dilemma is caused by economic and political interests that benefit from any weakness in the scientific underpinning of pleas for conservative catch rates (Paterson et al. 2013). Stronger stock assessment science is a necessary but not sufficient requirement for rebuilding Namibian hake stocks and for sustainable fisheries. The other requirements are for reduced total allowable catches and, more importantly, reduced mortality that together will permit stock recovery and restore biodiversity, where possible, to a level of greater resilience. Given that landings have not improved despite increased efficiency, it seems clear that the rebuilding of the Namibian hake stocks will not be achieved through "business as usual".

Responses to this article can be read online at: http://www.ecologyandsociety.org/issues/responses. $\mathrm{php} / 6370$ 


\section{Acknowledgments:}

This article is written as part of ECOFISH, which is a project of the Benguela Current Commission, the Technical University of Denmark, and the University of Cape Town. The views expressed in this paper are those of the authors and do not necessarily reflect the views of the Benguela Current Commission. Fieldwork in Namibia was also supported by the South African Research Chair in Marine Ecology and Fisheries. The African research project on knowledge production under University of Cape Town's programme for the enhancement of Research Capacity (PERC) funded a series of workshops on knowledge for an ecosystem approach to fisheries. Thanks to Astrid Jarre for support; to John Paterson for assistance with the analysis of logbook data; and to Lelsey Green, Barb Neis, and Rosemary Ommer for fruitful discussions about fishers' knowledge. Thanks also to the members of the Namibian hake fishery who provided support and shared their knowledge.

\section{LITERATURE CITED}

Agrawal, A. 1995. Dismantling the divide between indigenous and scientific knowledge. Development and Change 2:413-439. http://dx.doi.org/10.1111/j.1467-7660.1995.tb00560.x

Assorov, V. V., and D. Y. Berenbeim. 1983. Spawning grounds and cycles of Cape hakes in the southeast Atlantic. Collection of Scientific Papers of the International Commission for Southeast Atlantic Fisheries 10(i):27-30.

Bavington, D. L. Y. 2009. Creating manageable cod fisheries in Newfoundland and Labrador, Canada. Mast 7:99-121.

Beckley, L. E., and C. D. van der Lingen. 1999. Biology, fishery and management of sardines (Sardinops sagax) in southern African waters. Marine and Freshwater Research 50:955-978. http://dx.doi.org/10.1071/MF99068

Benguela Current Large Marine Ecosystem. 2006. Commercial fisheries rights holder and vessel analysis. Technical Report BCLME LMR/SE/03/03. BCLME, Windhoek, Namibia.

Bennet, E. J. 2008. Annual changes in spatial aggregation of Atlantic cod, Gadus morhua age classes in Divisions 2J3KL and 4RS (1978-1994). Dissertation. Memorial University of Newfoundland, St. John's, Newfoundland and Labrador, Canada.

Berkes, F. 2011. Restoring unity: the concept of marine socialecological systems. Pages 9-28 in R. E. Ommer, R. I. Perry, K. Cochrane, and P. Cury, editors. World fisheries: a social-ecological analysis. Wiley Blackwell, Oxford, UK. http://dx.doi. org/10.1002/9781444392241.ch2

Biernacki, P., and D. Waldorf. 1981. Snowball sampling: problems and techniques of chain referral sampling. Sociological Methods and Research 10(2):141-163.

Burmeister, L. 2005. Is there a single stock of Merluccius paradoxus in the Benguela ecosystem? African Journal of Marine Science 27:23-32.

Burmeister, L.-M. 2001. Depth-stratified density estimates and distribution of the Cape hake Merluccius capensis and $M$. paradoxus off Namibia deduced from survey data, 1990-1999. South African Journal of Marine Science 23(1):347-356.
Butterworth, D. S., and H. F. Geromont. 2001. Evaluation of a range of possible simple interim management procedures for the Namibian hake fishery. South African Journal of Marine Science 23:357-374. http://dx.doi.org/10.2989/025776101784528962

Carruthers, E. H., and B. Neis. 2011. Bycatch mitigation in context: using qualitative interview data to improve assessment and mitigation in a data-rich fishery. Biological Conservation 144:2289-2299. http://dx.doi.org/10.1016/j.biocon.2011.06.007

Davis, A., and J. R. Wagner. 2003. Who knows? On the importance of identifying "experts" when researching local ecological knowledge. Human Ecology 31(3):463-489.

Dawe, and Scheider. 2014. Paper title. Ecology and Society xx(yy): zz.

Draganik, B., and R. B. Sachs. 1991. An attempt to rearrange available calendar-year biostatistics on the Cape horse mackerel stock off Namibia on a reproductive-cycle basis, and the VPA results. South African Journal of Marine Science 11:153-168. http://dx.doi.org/10.2989/025776191784287727

Finlayson, A. C. 1994. Fishing for truth: a sociological analysis of northern cod stock assessments from 1977-1990. ISER Books, St. John's, Newfoundland and Labrador, Canada.

Gordoa, A., and C. M. Duarte. 1991. Size-dependent spatial distribution of hake (Merluccius capensis and Merluccius paradoxus) in Namibian waters. Canadian Journal of Fisheries and Aquatic Science 48:2095-2099. http://dx.doi.org/10.1139/f91-248

Gordoa, A., H. Lesch, and S. Rodergas. 2006. Bycatch: complementary information for understanding fish behaviour. Namibian Cape hake (M. capensis and M. paradoxus) as a case study. ICES Journal of Marine Science 63:1513-1519. http://dx. doi.org/10.1016/i.icesjms.2006.05.007

Gosse, K. R., and J. S. Wroblewski. 2004. Variant colourations of Atlantic cod (Gadus morhua) in Newfoundland and Labrador nearshore waters. ICES Journal of Marine Science 61(5):752-759. http://dx.doi.org/10.1016/j.icesjms.2004.04.003

Grant, W. S., R. W. Leslie, and I. I. Becker. 1987. Genetic stock structure of the southern African hakes Merluccius capensis and M. paradoxus. Marine Ecology Progress Series 41:9-20. http://dx. doi.org/10.3354/meps041009

Haggan, N., B. Neis, and I. G. Baird, editors. 2007. Fishers' knowledge in fisheries science and management. UNESCO, Paris, France.

Henning, E. 2004. Finding your way in qualitative research. Van Schaik, Pretoria, South Africa.

Hilborn, R., and C. J. Walters. 1992. Quantitative fisheries stock assessment. Choice, dynamics and uncertainty. Chapman and Hall, New York, New York, USA. http://dx.doi.org/10.1007/978-1-4615-3598-0

Hind, E. J. 2012. Translating fishers' knowledge into human capital: a way for fisheries managers to down-size industrial fleets and enable sustainable stewardship. Paper presented at the International Symposium on Rebuilding Collapsed Fisheries and Threatened Communities, 1-4 October 2012. Bonne Bay, Newfoundland and Labrador, Canada.

Hutchings, J. A. 1996. Spatial and temporal variation in the density of northern cod and a review of hypothesis for the stock's 
collapse. Canadian Journal of Fisheries and Aquatic Science 53:943-962. http://dx.doi.org/10.1139/f96-097

Iilende, T., T. Stromme, and E. Johnsen. 2001. Dynamics of the distribution of the pelagic component of Namibian hake stocks. South African Journal of Marine Science 23:337-346. http://dx. doi.org/10.2989/025776101784529024

Johannes, R. E., and B. Neis. 2005. The value of anecdote. Pages 41-58 in N. Haggan, B. Neis, and I. G. Baird, editors. Fishers' knowledge in fisheries science and management. UNESCO, Paris, France.

Johnsen, E., and I. Iilende. 2007. Factors affecting the diel variation in commercial CPUE of Namibian hake - can new information improve standard survey estimates? Fisheries Research 88:70-79.

Kainge, P., O. S. Kjesbu, A. Thorsen, and A. G. Salvanes. 2007. Merluccius capensis spawn in Namibian waters, but do $M$. paradoxus? African Journal of Marine Science 29(3):379-392.

Kirchner, C., P. Kainge, and J. Kathena. 2012. Evaluation of the status of the Namibian hake resource (Merluccius spp.) using statistical catch-at-age analysis. Environment for Development Discussion Paper Series October 2012. Environment for Development, Environment for Economics Unit, University of Gothenburg, Sweden.

Lutz, J. S., and B. Neis. 2008. Making and moving knowledge. Interdisciplinary and community-based research in a world on the edge. McGill-Queens University Press, Montreal, Quebec, Canada.

Marine and Inland Fisheries Service. 2011. Review of the state of world marine fishery resources. FAO Fisheries and Aquaculture Technical Paper No. 569. Fisheries and Aquaculture Resources Use and Conservation Division, FAO Fisheries and Aquaculture Department, Food and Agriculture Organization of the United Nations (FAO), Rome, Italy.

Maurstad, A. 2002. Fishing in murky waters: ethics and politics of research on fisher knowledge. Marine Policy 26:159-166. http:// dx.doi.org/10.1016/S0308-597X(01)00045-8

Millar, D., and J. Field. 2002. Distribution and abundance of Cape hakes in relation to environmental variation in the southern Benguela system. Southern African Marine Science Symposium (SAMSS 2002): Current Coast Communities. Swakopmund, Namibia.

Ministry of Fisheries and Marine Resources. 1991. Towards responsible development of the fisheries sector. White Paper. Government of the Republic of Namibia, Windhoek, Namibia.

Ministry of Fisheries and Marine Resources. 2004. Namibia's marine resources policy: towards sustainable development of the marine sector. Government of the Republic of Namibia, Windhoek, Namibia.

Ministry of Fisheries and Marine Resources. 2011a. Annual Report 2010/2011. MFMR, Windhoek, Namibia. [online] URL: http://209.88.21.36/opencms/export/sites/default/grnnet/MFMR/ downloads/docs/MIN_OF_FISHERIES_2036613.pdf.

Ministry of Fisheries and Marine Resources. 2011b. Management plan for the Namibian hake fishery. Draft presented for discussion at a national workshop, 25-26 January 2011, Walvis Bay, Namibia. Republic of Namibia, Walvis Bay, Namibia. [online] URL: http:// acpfish2-eu.org/uploads/projects/id7/Namibian $\% 20 \mathrm{Hake} \%$ 20Management $\% 20$ Plan $\% 20$ March $\% 202011$.pdf.

Murray, G. D., B. Neis, and J. Johnsen. 2006. Lessons learned from reconstructing interactions between local ecological knowledge, fisheries science, and fisheries management in the commercial fisheries of Newfoundland and Labrador, Canada. Human Ecology 34:549-71. http://dx.doi.org/10.1007/s10745-006-9010-8

Murray, G., B. Neis, C. T. Palmer, and D. C. Schneider. 2008. Mapping cod: fisheries science, fish harvesters' ecological knowledge and cod migrations in the northern Gulf of St. Lawrence. Human Ecology 36:581-598. http://dx.doi.org/10.1007/ $\underline{\text { s10745-008-9178-1 }}$

Myers, R. A., and N. G. Cadigan. 1995. Was an increase in natural mortality responsible for the collapse of northern cod? Canadian Journal of Fisheries and Aquatic Science 52:1274-1285.

Nadasdy, P. 1999. The politics of TEK: power and the 'integration' of knowledge. Arctic Anthropology 36:1-18.

Neis, B. 1992. Fishers' ecological knowledge and stock assessment in Newfoundland. Newfoundland studies 8:2.

Neis, B., and L. Felt, editors. 2000. Finding our sea legs: linking fishery people and their knowledge with science and management. ISER Books, St. John's, Newfoundland and Labrador, Canada.

Neis, B., L. Felt, R. L. Haedrich, and D. C. Schneider. 1999a. An interdisciplinary methodology for collecting and integrating fishers' ecological knowledge into resource management. Pages 217-238 in D. Newell and R. Ommer, editors. Fishing places, fishing people: issues and traditions in Canadian small-scale fisheries. University of Toronto Press, Toronto, Ontario, Canada.

Neis, B., and R. Kean. 2003. Why fish stocks collapse: an interdisciplinary approach to understanding the dynamics of 'fishing up'. Pages 65-102 in R. Byron, editor. Retrenchment and regeneration in rural Newfoundland. University of Toronto Press, Toronto, Ontario, Canada.

Neis, B., D. C. Schneider, L. Felt, R. L. Haedrich, J. Fischer, and J. A. Hutchings. 1999b. Fisheries assessment: what can be learned from interviewing resource users? Canadian Journal of Fisheries and Aquatic Sciences 56(10):1949-1963.

Ocean and Land Resource Assessment Consultants. 2013. Namibian hake fishery. OLRAC SPS, London, England. [online] URL: http://www.olsps.com/fisheries/proj2.html.

Olivar, M.-P., P. Rubiés, and J. Salat. 1988. Early life history and spawning of Merluccius capensis Castelnau in the northern Benguela current. South African Journal of Marine Science 6:245-254. http://dx.doi.org/10.2989/025776188784480672

Ommer, R. E., R. I. Perry, G. Murray, and B. Neis. 2012. Socialecological dynamism, knowledge, and sustainable coastal marine fisheries. Current Opinion in Environmental Sustainability 4:316-322. http://dx.doi.org/10.1016/j.cosust.2012.05.010

O'Toole, M. J. 1976. Distribution and abundance of the hake Merluccius spp. off South West Africa 1972-1974. Collection of Scientific Papers of the International Commission for Southeast Atlantic Fisheries 2:151-158. 
O'Toole, M. J. 1978. Aspects of the early life history of the hake, Merluccius capensis Castelnau, off South West Africa. Fisheries Bulletin of South Africa 10:20-36.

Paterson, B., C. Kirchner, and R. E. Ommer. 2013. A short history of the Namibian hake fishery-a social-ecological analysis. Ecology and Society 18(4):66.

Pauly, D., Christensen, V., Guénette, S., Pitcher, T. J., U. Sumaila, R., Walters, C. J., Watson R., and D. Zeller. 2002. Towards sustainability in world fisheries. Nature 418:689-695. http://dx. doi.org/10.1038/nature01017

Payne, A. I. L. 1995. Cape hakes. Pages 136-147 in A. I. L. Payne and R. J. M. Crawford, editors. Oceans of life off Southern Africa. Second edition. Vlaeberg, Cape Town, South Africa.

Pennington, M., and T. Stromme. 1998. Surveys as a research tool for managing dynamic stocks. Fisheries Research 37:97-106. http://dx.doi.org/10.1016/S0165-7836(98)00129-5

Petersen, S. L., M. B. Honig, P. G. Ryan, L. G. Underhill, and M. Goren. 2009. Seabird bycatch in the demersal longline fishery off southern Africa. African Journal of Marine Science 31 (2):205-214. http://dx.doi.org/10.2989/AJMS.2009.31.2.8.880

Rademeyer, R. A., Butterworth, D. S., and E. E. Plagányi. 2008. Assessment of South African hake resource taking its two species nature into account. African Journal of Marine Science 30 (2):263-290.

Roux, J.-P., and L. J. Shannon. 2004. Ecosystem approach to fisheries management in the northern Benguela: the Namibian experience. African Journal of Marine Science 26(1):79-93. http:// dx.doi.org/10.2989/18142320409504051

Sherbourne, R. 2010. Guide to the Namibian economy. Institute for Public Policy Research, Windhoek, Namibia.

Smedbol, R. K., and J. S. Wroblewski. 2002. Metapopulation theory and northern cod population structure: interdependency of subpopulations in recovery of a groundfish population. Fisheries Research 55:161-174. http://dx.doi.org/10.1016/S0165-7836 (01)00289-2

Soto, C. G. 2006. Socio-cultural barriers to applying fishers' knowledge in fisheries management: an evaluation of literature cases. Dissertation. Simon Fraser University, Burnaby, British Columbia, Canada.

Stanley, R. D., and J. C. Rice. 2003. Participatory research in the British Columbia groundfish fishery. Pages 44-56 in N. Haggan, C. Brignall, and L. Wood, editors. Putting fishers' knowledge to work, conference proceedings August 27-30, 2001, Fisheries Centre Research Reports Volume 11, Number 1. Fisheries Centre, University of British Columbia, Vancouver, British Columbia, Canada.

Stephenson, R., and E. Kenchington. 2000. Conserving fish stock structure is a critical aspect of preserving biodiversity. MiniSymposium on Defining the Role of ICES in Supporting Biodiversity Conservation, CM 2000/Mini:07. International Council for the Exploration of the Sea (ICES), Copenhagen, Denmark.
Stephenson, R. L., K. Rodman, D. G. Aldous, and D. E. Lane. 1999. An in-season approach to management under uncertainty: the case of the SW Nova Scotia herring fishery. ICES Journal of Marine Science 56:1005-1013. http://dx.doi.org/10.1006/jmsc.1999.0555

Sumaila, U. R., and M. Vasconcellos. 2000. Simulation of ecological and economic impacts of distant water fleets on Namibian fisheries. Ecological Economics 32:457-464. http://dx. doi.org/10.1016/S0921-8009(99)00120-2

Uanivi, U., N. Moroff, S. Petersen, and B. Paterson. 2010. Ecological risk assessment review of the Namibian midwater trawl fishery. Pages 380-425 in S. Petersen, B. Paterson, J. Basson, N. Moroff, J-P. Roux, J. Augustyn, and G. D'Almeida (editors). Tracking the implementation of an ecosystem approach to fisheries in Southern Africa (Volume 2). WWF South Africa Report Series - 2010/Marine/001. World Wildlife Fund South Africa, Cape Town, South Africa.

van der Westhuizen, A. 2001. A decade of exploitation and management of the Namibian hake stocks. South African Journal of Marine Science 23:307-315. http://dx.doi.org/10.2989/025776$\underline{101784529015}$

von der Heyden, S., M. R. Lipinski, and C. A. Matthee. 2007. Mitochondrial DNA analyses of the Cape hakes reveal an expanding, panmictic population for Merluccius capensis and population structuring for mature fish in Merluccius paradoxus. Molecular Phylogenetics and Evolution 42:517-527. http://dx.doi. org/10.1016/j.ympev.2006.08.004

Weinstein, M. 2012. TAMS Analyzer. Version 14.3b. Mayday Softworks, Tacoma, Washington, USA.

Wilhelm, M. R. 2012. Growth and otolith zone formation of Namibian hake Merluccius capensis. Dissertation. University of Cape Town, Cape Town, South Africa.

Wilson, J. A. 2006. Matching social and ecological systems in complex ocean fisheries. Ecology and Society 11(1):9 [online] URL: http://www.ecologyandsociety.org/vol11/iss1/art9/.

Worm, B., E. B. Barbier, N. Beaumont, J. E. Duffy, C. Folke, B. S. Halpern, J. B. C. Jackson, et al. 2006. Impacts of biodiversity loss on ocean ecosystem services. Science 314 (5800):787-790. http://dx.doi.org/10.1126/science.1132294 